\title{
ENTRE CONSCIÊNCIA INDIVIDUAL E AUTORIDADE ESTATAL: BREVES REFLEXÕES SOBRE A DESOBEDIÊNCIA CIVIL NO ESTADO DEMOCRÁTICO DE DIREITO
}

\author{
BETWEEN INDIVIDUAL AWARENESS AND STATE AUTHORITY: BRIEF REFLECTIONS ON \\ CIVIL DISOBEDIENCE AS LAW DEMOCRATIC
}

Andityas Soares de Moura Costa Matos*
Joyce Karine de Sá Souza

\begin{abstract}
Resumo
O presente artigo pretende demonstrar que a desobediência civil é um direito fundamental. Para tanto, discute-se a evolução do Estado e dos direitos fundamentais, passando pelas fases do Estado liberal, Estado Social e Estado Democrático de Direito. Em seguida, apresenta-se a uma breve análise histórica da ideia de desobediência civil, para ao final se discutir as características próprias desse instituto, que o diferenciam das demais formas de resistência à opressão. Por fim, são apresentadas normas de ordens jurídicas estrangeiras que fundamentam a tese desenvolvida neste artigo, as quais se baseiam nas formulações teóricas de Thomas Hobbes, John Locke, Santo Tomás de Aquino, Marquês de Sade e Henry David Thoreau, entre outros autores.
\end{abstract}

Palavras-chave: Desobediência Civil. Evolução do Estado. Direitos Fundamentais. Constitucionalismo. Filosofia do Direito.

\footnotetext{
* Possui Graduação em Direito pela Universidade Federal de Minas Gerais (2002), Mestrado em Filosofia do Direito pela Universidade Federal de Minas Gerais (2004) e Doutorado em Direito e Justiça pela Universidade Federal de Minas Gerais (2009). Atualmente é Professor Adjunto III de Filosofia do Direito e disciplinas afins na Faculdade de Direito da Universidade Federal de Minas Gerais (Graduação e Corpo Permanente da Pós-Graduação) e Professor Titular de Filosofia do Direito no curso de Direito da FEAD, em Belo Horizonte/MG. Diretor da Revista Brasileira de Estudos Políticos. Pesquisador colaborador no Departamento de Filosofia da Universidade Estadual de Campinas (UNICAMP). Coordena o Grupo de Pesquisa Kelsen integral: Leituras Políticas e Filosóficas da Obra de Hans Kelsen, além dos Projetos de Pesquisa Contra-história da filosofia do direito e do Estado: da Grécia ao estado de exceção e $\mathrm{O}$ estado de exceção no Brasil contemporâneo: para uma leitura crítica do argumento de emergência no cenário político-jurídico nacional. Tem experiência na área de Direito, com ênfase em Filosofia do Direito, Teoria do Direito e Filosofia Antiga, atuando principalmente nos seguintes temas: normativismo, teoria da justiça, decisionismo, estado de exceção, biopolítica, debate Kelsen e Schmitt, autoritarismo e democracia, filosofia antiga, filosofia pré-socrática e estoicismo.

*** Doutoranda em Direito pela Universidade Federal de Minas Gerais, possui Mestrado em Direito e Justiça pela Universidade Federal de Minas Gerais (2014) e Graduação em Direito pela FEAD-Minas (2012). Desde 08/2012 é professora no curso de Direito do Instituto de Nova Educação/Nova Faculdade (Contagem/MG). Participa dos Projetos de Pesquisa \&quot;Contra-história da filosofia do direito e do Estado: da Grécia ao estado de exceção\&quot; e \&quot; O estado de exceção no Brasil contemporâneo: para uma leitura crítica do argumento de emergência no cenário político-jurídico nacional\&quot;. Tem experiência na área de Direito e Política, com ênfase em Filosofia do Direito, Teoria do Estado e Filosofia Política. Sua pesquisa é orientada à investigação de temas como estado de exceção, contrapoderes e resistências, produção biopolítica da multidão na contemporaneidade, democracia e sociedade do espetáculo.
} 


\section{Abstract}

This paper will argue that civil disobedience is a fundamental right. We will discuss the evolution of the State and fundamental rights, through the phases of Liberal State, Social State and Democratic Rule of Law. We will also present the evolution of civil disobedience idea and discuss the characteristics of this institute which differentiates it from other forms of resistance to oppression. Finally, we present norms of foreign legal systems that support the thesis developed in this paper, which are based on the theoretical approaches of Thomas Hobbes, John Locke, Saint Thomas Aquinas, Marquis of Sade and Henry David Thoreau, among others.

Keywords: Civil Disobedience. State evolution. Fundamental Rights. Constitutionalism. Philosophy of Law.

$$
* * *
$$

Não poderá existir um governo em que a consciência, e não a maioria, decida virtualmente o que é certo e o que é errado? Um governo em que as maiorias decidam apenas aquelas questões às quais se apliquem as regras de conveniência? Deve o cidadão, sequer por um momento, ou minimamente, renunciar à sua consciência em favor do legislador? Então por que todo homem tem uma consciência? Penso que devemos ser homens, em primeiro lugar, e depois súditos. Não é desejável cultivar pela lei o mesmo respeito que cultivamos pelo direito. A única obrigação que tenho o direito de assumir é a de fazer a qualquer tempo aquilo que considero direito. [...] A lei jamais tornou os homens mais justos, e, por meio de seu respeito por ela, mesmo os mais bem-intencionados transformam-se diariamente em agentes da injustiça (THOREAU, 2008, pp. 10$11)$.

\section{Introdução}

O Direito e a Filosofia do Direito devem, necessariamente, considerar seus problemas teóricos à luz da decidibilidade (FERRAZ JÚNIOR, 2001), o que torna complexa a abordagem da questão relativa à desobediência civil, já que, na seara jurídica, a mesma não se põe apenas em um plano conceitual, mas antes prático, no qual se deve buscar uma decisão razoável, aplicável e eficaz. Ora, a desobediência civil sempre representou uma espécie de assunto proibido no amplo repositório de teorias, estruturas explicativo-compreensivas e noções que costumamos chamar de doutrina jurídica. 
A consolidação e a estruturação dos Estados modernos trouxeram questões até então não debatidas, mas que permeiam os cidadãos em uma sociedade organizada. Uma delas, se não a mais latente no mundo hodierno, é até onde vai o dever de obediência ao Estado quando os mandamentos jurídicos não coincidem com a consciência individual? O estatuto da subordinação determina exatamente os papéis do cidadão, sociedade e Estado na comunidade jurídica mediante a coercibilidade normativa, assegurando assim que todos os direitos e sanções sejam realizados sob a autoridade do Estado, direta ou indiretamente. No entanto, pergunta-se: quando o Estado ultrapassa os limites de sua atividade e interfere ativamente na livre esfera de seus cidadãos, estes devem se submeter às ordens, uma vez que a origem individual da consciência não é atingida frontalmente pelos mandamentos do Estado? Na verdade, tal questão remonta a Thoreau (2008), pai-fundador da desobediência civil: "Deve o cidadão, sequer por um momento, ou minimamente, renunciar à sua consciência em favor do legislador?”. Em outro momento o autor afirma que o Estado não enfrenta a consciência intelectual ou moral de um homem, mas o submete ao terror, subjugando seu corpo e seus sentidos com força física superior (THOREAU, 2008, p. 39).

Os limites da atividade estatal sobre o indivíduo foram delineados com a história à medida que os direitos fundamentais ganharam contornos jurídico-positivos. Em conjunto, a conduta humana começou a ser orientada pela ordem normativa e o cidadão passou a ser o destinatário dos direitos fundamentais assegurados pelo Estado na forma do direito positivo. Nesse processo histórico, a consciência individual do homem - cerne da desobediência civil, como se verá mais a frente - destaca-se na medida em que questiona o não cumprimento do pacto pelo Estado em assegurar os direitos ou o meio para que se realizem. Com uma postura éticodesobediente frente aos mandamentos estatais, o cidadão age de forma a não reconhecer a autoridade incondicional do Estado e da lei. A desobediência civil surge, assim, como forma de resistência à opressão que se opõe a concepções totalitárias de direito que exigem que os cidadãos sejam súditos em vontade e cegos em obediência tendo em vista uma idéia ética absoluta.

Para uma maior compreensão da desobediência civil, faz-se necessário um breve histórico da construção do Estado de Direito e dos direitos fundamentais, uma vez que estes 
surgiriam sobre o princípio de limitação da atividade estatal frente à comunidade jurídica. Afinal, Estado de Direito e direitos fundamentais têm uma profunda relação de identidade, o que se procurará elucidar.

\section{Estado de Direito e os Direitos Fundamentais}

A luta pela liberdade individual cerceada pelo Estado Absolutista deflagrou o surgimento do Estado de Direito na forma histórica de Estado Liberal, contrapondo o poder soberano do monarca e delimitando a esfera e a forma de atuação do Estado. A partir desse momento, o poder institucionalizado se baseou em um ordenamento jurídico objetivo para agir na forma de direito positivo. O Estado passou do "Eu Monarca" - atribui-se ao rei francês Luís XIV a famosa frase "L'État c'est moi"- para o "Eu Direito". Da mesma forma, as pessoas passaram de indivíduos para cidadãos, sujeitos de deveres e direitos. Como leciona José Afonso da Silva (2000, p. 108), a cidadania é “o reconhecimento do indivíduo como pessoa integrada na sociedade estatal [...]. Significa aí, também, que o funcionamento do Estado estará submetido à vontade popular. E aí o termo conexiona-se com o conceito de soberania popular [...], com os direitos políticos [...] e com o conceito de dignidade humana." Com a estruturação jurídica da vida em sociedade, consolida-se o conceito específico para denotar "Estado" dado por Kelsen (2000, p. 263):

O Estado como comunidade jurídica não é algo separado de sua ordem jurídica, não mais do que a corporação é distinta de sua ordem constitutiva. Uma quantidade de indivíduos forma uma comunidade apenas porque uma ordem normativa regulamenta sua conduta recíproca. [...] Como não temos nenhum motivo para supor que existam duas ordens normativas diferentes, a ordem do Estado e a sua ordem jurídica, devemos admitir que a comunidade a que chamamos "Estado" é a "sua" ordem jurídica.

Estado e direito são, então, faces diferentes da mesma moeda. Não há nenhum outro poder acima do Estado, porém, este poder é submetido ao direito. 
O art. 16 da Declaração dos Direitos do Homem e do Cidadão de 26 de agosto de $1789,{ }^{1}$ primeiro diploma legal de caráter universalista ${ }^{2}$ no qual se encontra positivado o núcleo básico dos direitos fundamentais, marco histórico do liberalismo francês da Revolução, dispõe: "A sociedade em que não esteja assegurada a garantia dos direitos nem estabelecida a separação dos poderes não tem Constituição ${ }^{3}$." O direito constitui, portanto, uma "autolimitação" do Estado, representando sua vontade e como esta será expressada. Ao cidadão são assegurados os direitos de liberdade, igualdade, propriedade, segurança e resistência à opressão. É composto o rol de direitos fundamentais de primeira geração ${ }^{4}$ de cunho liberal assumidos pelos revolucionários franceses de 1789. Com efeito, lê-se no art. $2^{\circ}$ da declaração: “A finalidade de toda associação política é a conservação dos direitos naturais e imprescritíveis do homem. Esses direitos são a liberdade, a propriedade, a segurança e a resistência à opressão ${ }^{5}$.

Com a imposição dos valores da burguesia e a crescente violação dos direitos por parte do Estado, foi-se desenvolvendo uma visão crítica da ordem liberal que garantia os “direitos fundamentais" aos burgueses, enquanto se acentuavam as diferenças socioeconômicas entre os

\footnotetext{
1 "La Declaración de 1789 y las Constituciones que siguen a esta fundamental declaración de principios de la libertad política supone el fin del Antiguo Régimen y la inauguración del Estado constitucional con la separación definitiva de las funciones que conforman la estructura administrativa de esa institución política". (CARVAJAL, 1992, p. 91). "A Declaração de 1789 e as Constituições que se seguem a esta fundamental declaração de princípios básicos da liberdade política implicam o fim do Antigo Regime e a inauguração do Estado constitucional com a separação definitiva das funções que conformam a estrutura administrativa dessa instituição política" (tradução nossa).

${ }^{2}$ Há outros antecedentes jurídico-históricos da positivação dos direitos fundamentais, como a declaração inglesa do Bill of Rights (1689) e a Declaração de Independência dos Estados Unidos (1776). No entanto, essas declarações têm caráter restrito, pois não inserem todos os indivíduos como cidadãos dentro da realidade de uma sociedade juridicamente organizada, limitando o alcance dos direitos a algumas pessoas em detrimento de outras. Nos Estados Unidos, por exemplo, a escravidão ainda era legítima e na Inglaterra a carta de direitos procurava proteger a liberdade religiosa e as garantias conferidas a todos os súditos protestantes. Com efeito, lê-se no Bill of Rights a exigência de "nenhuma interferência real na liberdade do povo de ter armas para sua própria defesa como adequado à sua classe e como permitido por lei (e ao mesmo tempo restaurar os direitos dos protestantes anteriormente tomados por James II)" (grifo nosso). Original: "No royal interference in the freedom of the people to have arms for their own defence as suitable to their class and as allowed by law (simultaneously restoring rights previously taken from Protestants by James II)." É com a Declaração francesa dos Direitos do Homem e do Cidadão que há uma garantia dos direitos civis e políticos para todos de forma abrangente, ultrapassando a esfera de certos indivíduos e procurando defender efetivamente o cidadão frente ao Estado, inclusive com a previsão do direito de resistir à opressão.

3 “Article XVI: Toute Société dans laquelle la garantie des Droits n'est pas assurée, ni la séparation des Pouvoirs déterminée, n'a point de Constitution".

${ }_{5}^{4}$ A expressão, um tanto quanto equívoca, é largamente utilizada por BOBBIO (1992).

5 "Article II: Le but de toute association politique est la conservation des droits naturels et imprescriptibles de l'homme. Ces droits sont la liberté, la propriété, la sûreté et la résistance à l'oppression".
}

R. Fac. Dir. UFG, v. 38, n. 2, p. 149 - 176, jul. /dez. 2014

ISSN 0101-7187 
cidadãos. De fato, o liberalismo tinha por pressuposto a não-interferência na ordem econômica, limitando-se em proteger a propriedade e o mercado, o que acentuava a desigualdade social e fragmentava a sociedade em grupos: os que tinham a possibilidade de adquirir bens e os que nem isso tinham. A igualdade era a igualdade jurídica frente ao dever-ser das normas, a liberdade consistia em não fazer aquilo proibido por lei e a opressão estatal aos poucos foi retomando destaque, o que poria um ponto final na forma histórica de Estado Liberal.

A partir desse momento o Estado de Direito toma a forma histórica de Estado Social, trata-se de um Estado capitalista que, porém, não anula os direitos de primeira geração, o que o diferencia do Estado Socialista, que concentra sob sua tutela todas as atividades econômicas, visando uma desvinculação com o capitalismo, o Estado é dominado pelo partido único, a cidadania torna-se opaca, uma vez que o que importa é a manutenção do Estado sob uma única ideologia e o poder estatal é usado para cercear e violar liberdades individuais, o que torna o Estado Socialista um totalitarismo, não Estado de Direito. Com crescente intervencionismo nas esferas econômica, política e jurídica, o Estado Social assume a missão de erradicar a desigualdade sustentada pela ordem liberal, trazer ao leque de proteção estatal os direitos sociais, garantindo o modo de sua promoção, e assegurar que os direitos individuais já consagrados deixassem de ter feição meramente formal, passando a ser garantido de forma homogênea para todos os cidadãos. As esferas do Direito Público e do Direito Privado estavam, então, bem definidas, com clara predominância da primeira sobre a segunda, ao contrário do que ocorria no Estado Liberal, quando o espaço do Direito Privado era nitidamente privilegiado diante do então ainda nascente Direito Público.

O que se seguiria era o surgimento da democracia de massas de signo totalitário, a qual faria com que os ideais do Estado Social se desvirtuassem. A supressão dos direitos de primeira geração, a intensa interferência na esfera íntima dos cidadãos, o exercício do poder de maneira unipessoal e a consolidação de um governo sem leis foram os princípios sobre os quais os alicerces necessários ao desenvolvimento do nacionalismo e do fascismo se ergueram. De cunho legalista, essas formas de Estado cerceariam o pluralismo político, converteriam a comunidade jurídica em uma grande máquina de manutenção do poder e iniciariam uma 
planificação e uniformização dos valores culturais. Hannah Arendt conclui que o totalitarismo é uma moderna forma de despotismo, onde há: "De um lado, o poder arbitrário, sem o freio das leis, exercido no interesse do governante e contra os interesses dos governados; e, de outro, o medo como princípio da ação, ou seja, o medo que o povo tem pelo governante e o medo do governante pelo povo [...].” (ARENDT, 1989, p. 513).

Sem dúvida, nazismo e fascismo não devem ser considerados à luz da teoria do Estado de Direito. Antes são formas ideológicas de submeter todos a uma ordem na qual não há o freio da lei, mas sua permissividade e fluidez diante todas as vontades do déspota. No Estado Total não se trata do dever de agir conforme o ordenamento jurídico, mas sim de uma completa falta de racionalidade que assume qualquer forma legislativa para manter o poder. No totalitarismo o terror é realizado sob a forma da vontade privada e não o direito, uma vez que o dever de obediência do Estado ao Direito é o que o faz um Estado de Direito. Assombra-nos, portanto, o pensamento de J. Périch, citado por Legaz y Lacambra, o qual reduz a noção de direito à noção de lei, com o dever incondicional de submissão à mesma:

Considerando que todo Estado é Rechtsstaat, porque não é possível um Ohnerechtsstaat, isto é, um Estado sem direito, estima supérflua e redundante a noção de Estado de Direito e declara que o Estado é idêntico ao "princípio da legalidade", que, para ele, equivale à autoridade incondicional da lei, o que impede a possibilidade de um direito de resistência dos súditos, que seria um "direito contra o Direito". (LEGAZ Y LACAMBRA, 1951, p. 15, tradução nossa) ${ }^{6}$

Como se percebe, trata-se de uma leitura equivocada e superficial da tese kelseniana segundo a qual direito e Estado são uma única realidade, eis que Kelsen, após identificar conceitualmente ambas as realidades, não faz defluir nenhuma consequência ética ou dever de obediência das suas doutrinas científicas, meramente descritivas e nunca apologéticas. Sem dúvida, a posição de Périch implica uma visão simplista, autoritária e utilitária do que seja um Estado de Direito. Ora, se o direito existe apenas para legitimar o poder soberano e as vontades do Estado nas mãos de quem quer que seja - visão que o reduz à lei - não faz sentido algum a

\footnotetext{
6 "Considerando que todo Estado es Rechtsstaat, porque no es posible un Ohnerechtsstaat, esto es, un Estado sin derecho, estima superflua y redundante la noción de Estado de Derecho y declara que el Estado es idéntico com el «principio de la legalidad», que para él equivale a la autoridad incondicional de la ley, que anula la posibilidad de un derecho de resistencia de los subditos, que sería un "derecho contra el Derecho»".
} 
existência de um ordenamento jurídico com hierarquia das normas, regras e limitações, ou seja, uma ordem jurídica formal e material que faz com que o cidadão reconheça (liberdade éticojurídica) e se convença (liberdade psicológica da vontade) ${ }^{7}$ sobre o dever de observar a legislação positiva. Ademais, esse "parêntesis histórico" da ascensão dos Estados nacionalistas totalitários mostra que quando se considera a construção do Estado de Direito meramente enquanto acidente ou casualidade do pensamento humano a noção de Estado regride aos moldes daquele que existiu no absolutismo. Como bem destacado por Legaz y Lacambra (1951, p. 15, tradução nossa):

Nem todo Estado é um Estado de Direito, mas este é o Estado cujo Direito tem uma específica estrutura e conteúdo em uma comunidade política. Neste sentido, ao Estado de Direito se contrapõe historicamente o Estado despótico, o Estado patrimonial, a ditadura, etc. De outro modo, todo Estado tem um conteúdo jurídico e ao Estado lhe é essencial o Direito, mas nem todo Estado enxerga no Direito valor fundamental integrante de sua essência, a razão de seu ser, a forma em que deve transcorrer sua atividade; e por isso, conceitualmente, ao Estado de Direito se opõem os conceitos de Estado de poder, de Estado de cultura, de Estado ético, de Estado econômico, etc. ${ }^{8}$

Com o fim dos Estados totalitários, entra novamente em voga a discussão sobre a proteção que se deve conferir continuamente aos direitos humanos fundamentais contra ações despóticas de qualquer espécie, consolidando-se o atual Estado de Direito de viés democrático, democracia essa que é exercida em sua forma indireta, no entanto, universal. A Declaração Universal dos Direitos Humanos da Organização das Nações Unidas, datada de 10 de dezembro de 1948, traz uma série de direitos elencados como sendo essenciais ao homem que convive em sociedade civil sob tutela jurídica estatal, "para que o homem não seja compelido, como último recurso, à rebelião contra a tirania e a opressão". ${ }^{9}$ A Declaração não tem natureza vinculativa,

\footnotetext{
${ }^{7}$ Termos cunhados por Legaz y Lacambra em seu artigo "El Estado de Derecho". Para o autor, o homem é radical e ontologicamente livre. Há liberdade ético-jurídica, ou seja, liberdade frente aos mandamentos das normas, e há liberdade psicológica da vontade, ou seja, liberdade frente à necessidade e ao determinismo da lei causal. (LEGAZ Y LACAMBRA, 1951, p. 19).

8 "No todo Estado es Estado de Derecho, sino que éste es el Estado cuyo Derecho dota de una específica estructura y contenido a una comunidad política. En este sentido, al Estado de Derecho se contraponen históricamente el Estado despótico, el Estado patrimonial, la dictadura, etcétera. De otra parte, todo Estado tiene un contenido jurídico y al Estado le es esencial el Derecho, pero no todo Estado ve en el Derecho el valor fundamental integrante de su esencia, la razón de su ser, la forma en que debe transcurrir su actividad; y por eso, conceptualmente, al Estado de Derecho se oponen los conceptos de Estado de poder, de Estado de cultura, de Estado ético, de Estado económico, etc".

9 "Considerando ser essencial que os direitos do homem sejam protegidos pelo império da lei, para que o homem não seja compelido, como último recurso, à rebelião contra a tirania e a opressão". (Declaração Universal dos Direitos Humanos, 1948). Original: "Whereas it is essential, if man is not to be compelled to have recourse, as a last resort,
} 
porém vários Estados-Nação se inspiraram nela para orientar suas Constituições como forma de positivar um núcleo de direitos necessários em uma era em que se verificou que quando o poder ilimitado é conferido ao Estado, sua legitimidade se faz mediante o terror e da barbárie, como observamos nos totalitarismos modernos, nazismo e fascismo.

Conforme Gilmar Ferreira Mendes (2002, p.2):

[...] os direitos fundamentais são, a um só tempo, direitos subjetivos e elementos fundamentais da ordem constitucional objetiva. Enquanto direitos subjetivos, os direitos fundamentais outorgam aos titulares a possibilidade de impor os seus interesses em face dos órgãos obrigados. Na sua dimensão como elemento fundamental da ordem constitucional objetiva, os direitos fundamentais - tanto aqueles que não asseguram, primariamente, um direito subjetivo, quanto aqueloutros, concebidos como garantias individuais - formam a base do ordenamento jurídico de um Estado de Direito democrático.

Quando os direitos fundamentais ganham positivação constitucional, esta determina o modo pelo qual as ações do Estado se orientarão e este realiza suas atividades conforme o direito. Forma-se assim o Estado de Direito. No entanto, ressalte-se que o rol de direitos fundamentais considerados atualmente não é exaustivo. Sua construção é gradual e não busca um fim. À medida que o homem passa por circunstâncias históricas em que há agressão, em qualquer de suas formas, aos direitos humanos fundamentais, seja por parte do Estado ou por parte de terceiros, põe-se a necessidade de proteger ainda mais sua essência de ser livre. Tal dever de proteção não se configura apenas na forma estatal, quando o Estado protege os direitos fundamentais contra as investidas do Poder Público em face do cidadão ou quando age como guardião desses direitos contra terceiros ${ }^{10}$. De fato, o maior interessado na proteção dos direitos humanos fundamentais é o próprio homem. Como cidadão, é legítimo que resista à opressão quando o Estado se torna um adversário ou se omite no dever de proteção aos seus direitos.

As razões pelas quais o "direito de se resistir à opressão" não foi referenciado nas Constituições liberais do século XIX que se basearam na Declaração Revolucionária de 1789 -

to rebellion against tyranny and oppression, that human rights should be protected by the rule of law."(The Universal Declaration of Human Rights, 1948).

${ }^{10}$ Tema abordado por Gilmar Ferreira Mendes no livro Hermenêutica Constitucional e Direitos Fundamentais, 2000 pp. 208-209.

R. Fac. Dir. UFG, v. 38, n. 2, p. 149 - 176, jul. /dez. 2014

ISSN 0101-7187 
pelo menos não de modo literal e claro, como se lê no art. $2^{\text {o11 }}$, nem nas modernas Constituições posteriores ao terror e à barbárie vividos pela humanidade durante a ascensão dos nacionalismos totalitários, são de ordem histórica e político-ideológica. Trata-se de um daqueles inumeráveis "esquecimentos" que o pensamento jurídico não aborda e finge não existir. Posição cômoda, porém irresponsável e anticientífica, como todas aquelas que privilegiam o útil em detrimento do verdadeiro.

A ideia de desobediência civil vem sendo sistematicamente desconsiderada tanto pela Filosofia do Direito quanto pela Teoria Geral do Direito. As razões desse fato se ligam, muitas vezes, a finalidades e objetivos políticos bastante específicos, uma vez que a teoria da desobediência civil possui conteúdo ideológico de feição naturalmente explosiva e contestatória. Ora, os valores da ordem e da segurança jurídica sempre foram privilegiados pelo pensamento jurídico ocidental, de maneira que a aceitação da desobediência civil como categoria integrante da dogmática tradicional mostra-se, se não paradoxal, ao menos problemática.

Contudo, faz-se necessário debater o tema da desobediência civil na seara do Direito, uma vez que a ciência jurídica não se encerra na dogmática tradicional e positivada, nem se limita a ela. Para tanto, abordaremos a desobediência civil enquanto postura ética relacionada ao direito de resistência, localizando-a em sua prática na história da humanidade, em pontos específicos. Ao final, trataremos de sua íntima relação com os direitos fundamentais.

\section{Desenvolvimento Histórico da Desobediência Civil}

A desobediência civil é tão antiga quanto o próprio direito ocidental, como o prova Antígona, a célebre tragédia de SÓFOCLES (1970). Na história, a personagem questiona o édito de Creonte, rei de Tebas, que proíbe o sepultamento de Polinice, irmão de Antígona, por ter intentado contra o governo enquanto disputava o trono com seu irmão Etéocles. Os irmãos se

\footnotetext{
11 “Art. 2. ${ }^{\circ}$ A finalidade de toda associação política é a conservação dos direitos naturais e imprescritíveis do homem. Esses direitos são a liberdade, a propriedade, a segurança e a resistência à opressão." Original: "Article II: Le but de toute association politique est la conservation des droits naturels et imprescriptibles de l'homme. Ces droits sont la liberté, la propriété, la sûreté et la résistance à l'oppression".
} 
mataram na busca pelo poder. Creonte, tio de Antígona, assumiu o governo de Tebas e aceitou o sepultamento de Etéocles, enquanto que para Polinice, considerado traidor, o tirano nega o direito ao sepultamento. A pena para quem enterrasse Polinice seria a condenação à morte. Diante do dever de obediência aos mandamentos da lei dos homens, Antígona, em conversa com sua irmã Ismênia, contesta a validade da norma e faz notar a injustiça que resultaria de seu cumprimento:

Certamente! Pois não sabes que Creonte concedeu a um de nossos irmãos, e negou ao outro, as honras da sepultura? Dizem que inumou a Etéocles, como era de justiça e de acordo com os ritos, assegurando-lhe um lugar condigno entre os mortos, ao passo que, quanto ao infeliz Polinice, ele proibiu aos cidadãos que encerrem o corpo num túmulo, e sobre este derramem suas lágrimas. Quer que permaneça insepulto, sem homenagens fúnebres, e presa de aves carniceiras. Tais são as ordens que a bondade de Creonte impõe a mim, como também a ti, e, eu o afirmo: ele próprio virá a este sítio comunicá-las a quem ainda as ignore. Disso faz ele empenho, e ameaça, a quem quer que desobedeça, de ser apedrejado pelo povo. [...] Uma coisa é certa: Polinice era meu irmão, e teu também, embora recuses o que eu te peço. Não poderei ser acusada de traição para com o meu dever. [...] Ele não tem o direito de me coagir a abandonar os meus! (SÓFOCLES, 2005, pp. 6-8).

Antígona, em um ato de coragem, assume postura ético-desobediente e enterra o cadáver de Polinice, defendendo e exercendo seu direito de sepultá-lo. Creonte, firme em sua posição tirânica, executa Antígona cumprindo o determinismo da lei e afirma que a cidade pertence a seu governante. A execução de Antígona serviria de exemplo para qualquer cidadão de Tebas que desobedecesse aos mandamentos da lei. Mantendo a pedagogia do terror, Creonte executa seu filho Hémon por ter defendido o direito de Antígona em enterrar Polinice e suplicado por sua vida. Interrogada por Creonte para averiguar se ela sabia sobre a existência da normativa em tela, Antígona responde:

Sim, eu sabia! Por acaso poderia ignorar, se era uma coisa pública? [...] não foi Júpiter que a promulgou; e a Justiça, a deusa que habita com as divindades subterrâneas jamais estabeleceu tal decreto entre os humanos; nem eu creio que teu édito tenha força bastante para conferir a um mortal o poder de infringir as leis divinas, que nunca foram escritas, mas são irrevogáveis; não existem a partir de ontem, ou de hoje; são eternas, sim! - Tais decretos, eu, que não temo o poder de homem algum, posso violar sem que por isso me venham a punir os deuses! Que vou morrer, eu bem sei; é inevitável; e morreria mesmo sem a tua proclamação. E, se morrer antes do meu tempo, isso será, para mim, uma vantagem, devo dizê-lo! Quem vive, como eu, no meio de tão lutuosas desgraças, que perde com a morte? Assim, a sorte que me reservas é um mal que 
não se deve levar em conta; muito mais grave teria sido admitir que o filho de minha mãe jazesse sem sepultura; tudo o mais me é indiferente! Se te parece que cometi um ato de demência, talvez mais louco seja quem me acusa de loucura! [...] Por que demoras, pois? Em tuas palavras tudo me causa horror, e assim seja sempre! Também todos os meus atos te serão odiosos! Que maior glória posso eu pretender, do que a de repousar no túmulo de meu irmão? Estes homens (indica o coro) confessariam que aprovam o que eu fiz, se o terror não lhes tolhesse a língua! Mas, um dos privilégios da tirania consiste em dizer, e fazer, o que quiser. (SÓFOCLES, 2005, pp. 30-33, grifo nosso).

Na doutrina teológica de Santo Tomás de Aquino (1225-1274), a lei humana, fruto de uma convenção, se subordina à lei natural ${ }^{12}$ na qual o legislador deve se basear, verificando o que ela preceitua. Por tal razão metafísica, os homens não devem desobedecer às leis humanas. No entanto, caso uma lei positiva represente uma afronta à lei natural, justifica-se a desobediência à norma, dado que não refletirá o postulado por Deus nas leis divinas. Caso fosse positivado pelo legislador o que não está em consonância com a lei natural, leis injustas seriam institucionalizadas, o que, para Santo Tomás, engendra um direito ilegítimo e contrário aos preceitos da ordem divina. Tal seria, na visão tomista, apenas um direito corrupto (corruptio legis), não verdadeiro direito, estando os homens de acordo com as leis divinas quando resistem aos mandamentos do que foi criado contrariamente aos mandamentos jusnaturais.

Por certo, tanto em Sófocles quanto em Santo Tomás, ou seja, da Grécia até a Idade Média, vemos a justificação da desobediência à lei no plano do divino, o que simboliza a submissão do direito à crença em uma ordem superior que valida as ações humanas frente às leis positivadas. Foi com o início do movimento iluminista no século XVII que as esferas do divino e do jurídico começaram a se separar e todo conhecimento crítico produzido nessa época por Isaac Newton, Voltaire, John Locke, Montesquieu, Benjamin Franklin, Jean-Jacques Rousseau, Immanuel Kant, para citar apenas alguns autores, influenciou os movimentos que afastariam a religião do poder político, como ocorreu na Inglaterra com Revolução Gloriosa de 1688 e na França revolucionária de 1789 com a Declaração dos Direitos do Homem e do Cidadão. Não obstante, frisa-se que não se pretende fazer um apanhado geral do direito de resistência e da

\footnotetext{
12 "A lei natural (lex naturalis) representa, na teoria tomista, uma participação racional na lei eterna (lex aeterna) [promulgada por Deus], sorte de retificação de algo que possui quintessência espiritual; a natureza está prenhe do que é divino, e, portanto, retrata, em parte, leis divinas" (BITTAR, Teorias sobre a justiça: apontamentos para a história da filosofia, 2000, pp. 123-151).
} 
desobediência civil ao longo da história, mas apenas breves indicações pontuais - porém fundamentais - para a compreensão de sua construção histórico-jurídica.

Na teoria contratualista de Thomas Hobbes (1588-1679) a desobediência civil toma caráter revolucionário, uma vez que o dever de obediência à lei é intrínseco ao pacto para que o Estado Leviatã se concretize. Rompê-lo é injusto, sendo o poder soberano irresistível. A submissão a tal poder seria necessária para a manutenção da vida dos homens em sociedade. No entanto, torna-se legítima a desobediência civil quando o soberano atenta contra a vida dos homens e quando o Estado Leviatã mostra-se ineficiente em assegurá-la, o que tornaria justa a resistência ao soberano e a desobediência à lei, não sendo o pacto cumprido pela parte cuja obrigação essencial é garantir o direito à vida, a segurança e a paz entre os homens. Nessas situações não haveria justiça em se submeter ao poder soberano como súdito. Como afirma categoricamente Hobbes:

Se o soberano ordenar a alguém (mesmo que justamente condenado) que se mate, se fira ou se mutile a si mesmo, ou que não resista aos que o atacarem, ou que se abstenha de usar os alimentos, o ar, os medicamentos, ou qualquer outra coisa sem a qual não poderá viver, esse alguém tem a liberdade de desobedecer.. [...] Entende-se que a obrigação dos súditos para com o soberano dura enquanto, e apenas enquanto, dura também o poder mediante o qual ele é capaz de protegêlos. [...] A soberania é a alma do Estado, e uma vez separada do corpo os membros deixam de receber dela seu movimento. O fim da obediência é a proteção, e seja onde for que um homem a veja, quer em sua própria espada quer na de um outro, a natureza manda que a ela obedeça e se esforce por conservála. (HOBBES, capítulo XXI, pp. 75-76).

Desta maneira, pode-se sustentar com acerto que a desobediência civil na narrativa hobbesiana é legítima quando o soberano e o Estado Leviatã atentam contra o direito à vida, fundamental direito do homem. O que não implica uma falta de lógica ${ }^{13}$ no sistema hobbesiano,

\footnotetext{
${ }^{13}$ Como bem concluído por BRONDANI em sua Dissertação de Mestrado: "O conflito é evidente por que o súdito tem direito à resistência e o soberano tem direitos que lhe conferem um caráter irresistível. Quando o soberano impõe uma ordem que ameaça a vida do súdito este tem direito de resistir. No plano jurídico há um fundamento para o direito do súdito e para o soberano. O que ocorre então é que ambos fazem valer o seu direito e se dá então o conflito no âmbito da prática. Neste momento volta-se às relações de poder, e, de certa maneira, impera novamente a mesma lei do mais forte, válida no estado de natureza. Este plano de conflito é o das relações de poder, mas, é importante frisar, é a própria estrutura jurídica de Hobbes que abre espaço para o conflito, visto que o filósofo fundamenta tanto os direitos do soberano quanto o direito à resistência. [...] Não há uma incoerência lógica, ao se pensar a coexistência de direitos aparentemente contrários. Estes direitos são contrários no plano dos fatos. Ao ser ameaçado, o súdito tem
} 
uma vez que a possibilidade de autodefesa é a essência da preservação da própria vida. Ademais, é em razão da autonomia da vontade e do reconhecimento de que os homens em estado de natureza são incapazes de assegurar a manutenção à própria vida que se funda o pacto com o Estado. Se este não cumpre sua prerrogativa de garantir a segurança dos indivíduos em uma sociedade civil "ninguém é considerado obrigado pelo pacto a abster-se de resistir à violência" (HOBBES, capítulo XXVIII, p. 104).

Outro contratualista que defende o direito de se resistir às leis e de desobedecer aos seus mandamentos é John Locke (1632-1704). Para esse teórico é necessário que os homens vivam sob estado civil, tendo um juiz comum, uma vez que no estado de natureza a convivência pacífica é insustentável. No entanto, Locke defende a desobediência às leis e a resistência ao soberano quando este não busca o bem comum da sociedade organizada, mas tão somente seus interesses. A finalidade da sociedade política é a proteção ao direito de propriedade do homem, que para Locke se encontra no mesmo patamar dos direitos à vida e à liberdade. $\mathrm{O}$ direito à propriedade existe desde o estado de natureza, resultado do esforço do homem na transformação da natureza para sua existência.

Diferenciando poder paterno (sociedade familiar), poder político (sociedade civil) e poder despótico (escravidão) ${ }^{14}$, Locke demonstra que o dever de obediência ao soberano somente é exigível quando os homens se tornam súditos por aderirem ao pacto e este é cumprido pelas partes:

O poder paterno está aquém do poder do magistrado na mesma medida em que o poder despótico está além; e que o domínio absoluto, onde quer que esteja

direito de resistir ao soberano. Mas, é uma exigência da própria lógica jurídica de Hobbes o fato de que tanto o soberano tem direito de ameaçar o súdito, quanto o súdito tem direito de se defender. Toda a argumentação de Hobbes a respeito reforça esta conclusão. O Estado seria inviável se não houvesse os direitos do soberano. E também o seria se não houvesse o direito à resistência" (BRONDANI, 2007, p. 131).

14 "Neste contexto, o Segundo Tratado buscou 'demonstrar que o que distingue as três formas de sociedade é o diferente fundamento da autoridade e, portanto, da obrigação de obediência, ou seja, o diverso princípio de legitimidade'. São três as formas de obediência: do filho para com o pai, baseada na natureza; do escravo para com o senhor, baseada em um delito ou castigo; e a obrigação do súdito com o soberano, nascida de um contrato. Por isso, o soberano precisa de consentimento para que sua autoridade tenha valor (ao contrário do pai e do senhor). Um soberano que governa como um pai (Estado paternalista) ou como um senhor de escravos (Estado despótico) não tem legitimidade e os súditos não têm obrigação de obedecer" (GUADALUPE SILVEIRA 2008, pp. 218-231). 
situado, está tão longe de ser uma espécie de sociedade civil que é incompatível com ela, na mesma medida em que a escravidão o é com a propriedade. O poder paterno existe apenas enquanto a menoridade torna o filho incapaz de gerir sua propriedade; o político, quando os homens têm a propriedade à sua disposição; e o despótico, sobre aqueles que não possuem propriedade alguma. (LOCKE, 1994, pp. 189-190).

De fato, é apenas quando exerce o poder político que o soberano assegura a liberdade e a propriedade aos súditos, sendo o exercício do poder despótico contra tais direitos um atentado dirigido à vida dos homens, caso em que não devem obrigar-se ao dever de obediência às leis do déspota. Haveria uma regressão do estado civil para o estado de natureza, os homens seriam escravos e o soberano, senhor. Os direitos da consciência são preservados dentro do microsistema individual e, em situações de opressão, se exteriorizam no macro-sistema (sociedade civil) sob a forma da desobediência civil, uma resistência à opressão quando se impõe um dever absoluto de obediência a um "Estado" despótico, não havendo consenso entre governantes e governados.

Em Donatien Alphonse-François, o Marquês de Sade (1740-1814), a desobediência civil ganha contornos incisivos e práticos. Para além da teorização do direito de resistir à opressão, Sade pôs a nu a natureza dos princípios Igualdade, Liberdade e Fraternidade sobre os quais se erguia uma revolução na qual todos eram vítimas e carrascos. O autor foi perseguido e preso, sendo condenado tanto pelo Antigo Regime quanto pela França pós-revolucionária de 1789. Ou seja, Sade foi perseguido pela Monarquia, pela Primeira República, pelo Império e pela Restauração. Ficou preso durante vinte e sete anos, tendo passado por Vincennes, pela Bastilha, pelo hospício de Charenton, além de viver os quatro últimos anos de sua vida sob o peso de um decreto do Ministro do Interior, Conde do Império, no qual o Estado francês determinava:

Art. $1^{\circ}$. O Sr. de Sade será alojado em um local completamente isolado de modo que toda comunicação, com o interior ou o exterior, seja-lhe proibida contra qualquer pretexto que invoque. Ter-se-á o especial cuidado de lhe proibir todo uso de lápis, tinta, pena e papel. (In: SADE, 2005, p.77, tradução nossa) ${ }^{15}$

\footnotetext{
15 “Art. $1^{\circ}$. El Sr. de Sade será alojado en un local completamente asilado de modo que toda comunicación ya sea con el interior o con el exterior le sea prohibida, aún contra cualquier pretexto que invocase. Se tendrá especial cuidada de prohibirle todo uso de lápices, tinta, pluma y papel."
} 
Em uma época na qual não se falava impunemente a respeito dos desmandos do poder, o Marquês entregou sua vida no cárcere à atividade da escrita, que, com potencial ofensivo, provocou a ira do governo por narrar os horrores do despotismo sobre os quais, ironicamente, se erguia a revolução que procurava a liberdade, a igualdade e a fraternidade entre os homens. De fato, a Revolução Francesa, incoerente com seus princípios, foi um veículo para a barbárie:

Liberdade? Ninguém nunca foi menos livre, dir-se-ia um rio de sonâmbulos. Igualdade? Não há nenhuma igualdade, a não ser a das cabeças decepadas. Fraternidade? A delação nunca foi tão ativa. Se a intenção fosse pôr a nu o nó das paixões humanas, que encerram a aniquilação de todos por todos, o sucesso não teria sido maior. Sim, todos querem a morte de todos, isto é verdade (SADE in SOLLERS, 2001, p. 73).

A escrita foi a maior arma do Marquês contra as ações despóticas do poder soberano. Com palavras libertinas Sade aduz que o exercício da liberdade frente a mandamentos que exijam a renúncia total das vontades individuais é o direito que cada homem deve defender diante um "Estado" adversário dos próprios súditos. Em seu livro A Filosofia na Alcova (1795), o Marquês narra a história da educação de uma jovem casta nos moldes libertinos. Porém, quando se chega no capítulo "Franceses, mais um esforço se quereis ser republicanos", vemos que a obra almeja algo para além de aulas de libertinagem, pois

[...] acaba no fundo se estendendo a todo cidadão francês [...] Nesta obra, vários tipos de discurso (moral, político, estético) subordinam-se à linguagem erótica, que, por sua vez, se serve da linguagem revolucionária para combater os costumes e a religião (BORGES, in A Filosofia na Alcova, 2008, p. 206).

O poder do gozo ${ }^{16}$ descrito pelo Marquês ganha contornos políticos incisivos. Sade sugere a desobediência civil contra certas leis que arruinariam o sonho dos franceses em se manter como República, dentre elas a que previam a pena de morte e as que tipificavam delitos religiosos. Segundo o Marquês, leis que tolham a vida e a consciência individual não passam de instrumentos para castrar ou coibir a liberdade do homem. Para Sade, é dever do cidadão no

\footnotetext{
${ }^{16}$ Definido por Pina e Souza (1993, p. 30), “[...] como uma sensação prazerosa de embriaguez, de dissolução da consciência, de perda de limites, designada como morte, aniquilamento ou quebra, e que instaura um vazio que permite a introdução de uma nova ordem".
} 
Estado republicano fazer impor sua consciência em relação ao poder soberano de seres supremos. Afinal, se os homens têm liberdade de consciência, têm também liberdade de agir em nome e em defesa dela, sendo que as normas jurídico-estatais jamais conseguem atingir a razão de cada ser humano.

Os mandamentos dos que disputam o poder não passam de receitas engessadas para manter os homens sob o jugo da opressão. Para Sade, o único despotismo que um Estado republicano deveria admitir é o "despotismo da luxúria". Eis o terror do Estado, esse desejo permanente de transgressão intrínseco em cada ser humano, desencadeado quando as instituições político-jurídicas não se submetem ao direito ou constroem e mantém um arcabouço normativo que violenta a liberdade, tornando-a impraticável mediante mecanismos de adestramento próprios do discurso dominante.

As referências históricas da desobediência civil são várias, sendo que os autores citados representam apenas uma amostragem, ainda que significativa. Todavia, mesmo sem contorno jurídico-normativo fixo, sua prática precede seu conceito. Nesse sentido, faz-se necessário dedicar especial atenção ao pai-fundador da desobediência civil, Henry David Thoreau (1817 -1862), que com a obra intitulada A Desobediência Civil leva o tema a proporções teóricas abrangentes, influenciando, por exemplo, Gandhi na luta pela independência do povo indiano. Este ensaio é a primeira obra que postula a desobediência civil como um direito legítimo de resistir ao poder despótico quando este realiza ações que vão contra a consciência individual dos cidadãos. Para Thoreau:

[...] o melhor governo é o que governa menos [...], [sendo] apenas a maneira escolhida pelo povo para executar sua vontade. [...] Pois o governo é uma conveniência pela qual os homens conseguem, de bom grado, deixar-se em paz uns aos outros, e, como já se disse, quanto mais conveniente ele for, tanto mais deixará em paz seus governados (THOREAU, 2008, pp. 7-9).

Thoreau defende o fim da escravidão e se levanta contra os abusivos impostos que patrocinavam a Guerra Mexicana, na qual os Estados-Unidos enfrentaram o México de 1846 a 
1848 na disputa por anexação de territórios. Thoreau foi preso por sonegação em $1846,{ }^{17}$ tendo se recusado a pagar impostos a um Estado escravocrata e beligerante. Inspirado por esse episódio, ele escreveu seu fulgurante ensaio A Desobediência Civil em defesa do princípio da autonomia e da liberdade individual, sugerindo que todos os cidadãos reproduzissem sua postura de "resistência ao governo civil" ${ }^{18}$ que impõe aos governados que se portem como súditos e não como cidadãos, negando-lhes suas próprias consciências. Seja em termos práticos ou econômicos, Thoreau requer que seja retirado o apoio a um governo que legitima injustiças. A obediência a um "Estado" despótico passa de amoral à imoral quando o cidadão apoia suas ações em uma perspectiva conformista. Para Thoreau, se a democracia assim se mantivesse, mostrar-seia enquanto trunfo obtuso, não sendo mais do que a reunião de seres autônomos que livremente escolheram manter um Estado totalitário:

Será a democracia, tal como a conhecemos, o último desenvolvimento possível em matéria de governo? Não será possível dar um passo mais além no sentido do reconhecimento e da organização dos direitos do homem? Jamais haverá um Estado realmente livre e esclarecido até que este venha a reconhecer o indivíduo como um poder mais alto e independente, do qual deriva todo seu próprio poder e autoridade, e o trate de maneira adequada. Agrada-me imaginar um Estado que, afinal, possa permitir-se ser justo com todos os homens e tratar o indivíduo com respeito, como um seu semelhante; que consiga até mesmo não achar incompatível com sua própria paz o fato de uns poucos viverem à parte dele, sem intrometer-se com ele, sem serem abarcados por ele, e que cumpram todos os seus deveres como homens e cidadãos. Um Estado que produzisse este tipo de fruto, e que o deixasse cair assim que estivesse maduro, prepararia o caminho para um Estado ainda mais perfeito e glorioso, que também imaginei, mas que ainda não avistei em parte alguma (THOREAU, 2008, pp. 57-58).

Se o poder emana do povo, este deve manter uma postura ético-desobediente frente aos mandamentos contidos em normas que legitimam a opressão, tais como as que obrigam o indivíduo a patrocinar atrocidades do poder público para então considerá-lo enquanto sujeito de direitos. Um Estado que enfrenta o homem para além da esfera do ser-cidadão pretende transformar a democracia em tirania, em sua forma mais agressiva. Dar à democracia e aos direitos fundamentais aspecto meramente formal, cerceando sua materialidade, é típico de um

\footnotetext{
${ }^{17}$ Sugerimos a leitura do blog http://lendowalden.blogspot.com, mantido por Denise Bottmann, tradutora do livro Walden de Henry David Thoreau, edição da L\&PM, 2010. Além de reunir notas variadas de leitura e de tradução de Walden, o site contém uma série de referências sobre a obra e a vida do autor.

18 Título dado originalmente por Thoreau à sua obra A Desobediência Civil.
} 
Estado que não se conforma ao direito, mas que tenta deturpar a obrigação ética do indivíduo de ser convencido frente aos mandamentos jurídicos, procurando tolher-lhe, inclusive, a liberdade psicológica da vontade. É o Estado, nesse caso, representante do terrorismo institucionalizado e capitaneado por princípios totalitários, tal como descrito por Ernesto Garzon Valdes (1989, p. 52, tradução nossa):

Dito com outras palavras: quando o governo se transforma em agente do terror indiscriminado ou difuso, volta a criar as condições próprias do estado de natureza, no qual a vida do homem se torna "desagradável, brutal e curta", para usar a conhecida formulação de Hobbes. É a "tese do uivo", a que me referi anteriormente: o governo abandona seu papel de executor das leis vigentes para se transformar em adversário da luta pelo poder. Neste sentido, o terrorismo de Estado acaba minando as próprias bases de justificação da organização política e contribui para sua instabilidade. O terrorismo de Estado não pode ser uma forma permanente de governo. Assim o reconhecem também aqueles que o propiciam ou praticam quando destacam o caráter transitório deste tipo de sistema como etapa preparatória para uma "democracia verdadeira". Do ponto de vista ético, aplicar o "governo uivo" como uma forma de fortalecer a democracia é tão inaceitável como promover a morte intencional de inocentes para intimidar os culpados reais ou prováveis. ${ }^{19}$

Na teoria de Thoreau o direito de se resistir aos mandamentos da lei vai além de uma simples insubmissão às ordens jurídicas. Mesmo não encontrando positivação estatal, a desobediência civil é legítima, tratando-se de uma forma de estranhamento ao dogmatismo autoritário que enseja a opressão e mantém uma pseudo-democracia para legitimar suas atrocidades.

\section{Contornos Jurídicos da Desobediência Civil}

\footnotetext{
19 "Dicho con otras palabras: en el momento en que el gobierno se transforma en agente del terror indiscriminado o difuso vuelve a crear las condiciones propias del estado de naturaleza en el que la vida del hombre se vuelve 'desagradable, brutal y corta', para usar la conocida formulación de Hobbes. Es la 'tesis del aullido', a la que me he referido anteriormente: el gobierno abandona su papel de ejecutor de las leyes vigentes para transformarse en contendiente de la lucha por el poder. En este sentido, el terrorismo de Estado termina socavando las propias bases de justificación de la organización política y contribuye a su inestabilidad. El terrorismo de Estado no puede por ello ser nunca una forma permanente de gobierno. Así lo reconocen también quienes lo propician o practican cuando subrayan el carácter transitorio de este tipo de sistema como etapa preparatoria para una 'democracia verdadera'. Desde el punto de vista ético, postular el 'aullido gubernamental' como vía para el afianzamiento de la democracia es tan inaceptable como propiciar la muerte intencional de inocentes para amedrentar a los culpables reales o probables".
} 
De acordo com Barrington Moore Jr. (1987) e Nelson Nery Costa (2000), a desobediência civil pode ser entendida como uma postura política individual que, mediante ação organizada e consciente, contesta a supremacia e a validade da ordem jurídica vigente em sua inteireza ou em pontos isolados que, no entanto, conformam o arcabouço essencial de tal ordem. Bem se vê que a desobediência civil não é uma simples revolta ou negativa de cumprimento de normas jurídicas quaisquer. Trata-se, evidentemente, de uma revolta qualificada, e que normalmente busca um objetivo maior, ou seja, o desobediente se orienta rumo a uma finalidade que transcenda a mera negativa de cumprimento de determinados mandamentos legais. Da mesma maneira, pode-se sustentar com acerto que a desobediência civil não se assemelha e nem dá lugar, necessariamente, à anarquia pura e simples, que é a ausência de qualquer ordem jurídica. De acordo com Bobbio (2000), o anarquismo enquanto teoria constitui-se como negativa apriorística de qualquer governo, dado que o anarquista típico mantém uma firme e constante convicção segundo a qual jamais deve se submeter à heteronomia do tipo jurídico-estatal.

Também não se confunde a desobediência civil com a objeção de consciência, uma vez que esta preceitua uma contraprestação do objetor caso este não concorde com o mandamento da norma, tal como ocorre com a recusa de prestação de serviço às Forças Armadas por motivos ético-filosóficos. O instituto da objeção de consciência é geralmente positivado nos ordenamentos jurídicos ${ }^{20}$ como uma forma de atenuar a tensão entre Estado e cidadãos na convivência sob o pacto social. No entanto, caso o objetor não cumpra a contraprestação estipulada pelo Estado, será sancionado por desobedecer ao mandamento, o que distancia a objeção de consciência da desobediência civil, uma vez que esta não teme a sanção, por ir frontalmente contra a existência da norma injusta. O objetivo do desobediente é demonstrar que a injustiça não se coaduna com as idéias pelas quais se sustenta o Estado de Direito.

A desobediência civil não se define pela negativa de qualquer ordem, de qualquer governo e de qualquer direito. Trata-se, ao contrário, de questionar e de resistir a uma específica ordem, a um tipo de governo e a um particular direito, que, por diversas razões, são tidos por

\footnotetext{
${ }^{20}$ No nosso caso, temos o art. $5^{\circ}$, VIII, da Constituição da República Federativa do Brasil: "ninguém será privado de direitos por motivo de crença religiosa ou de conviç̧ão filosófica ou política, salvo se as invocar para eximir-se de obrigação legal a todos imposta e recusar-se a cumprir prestação alternativa, fixada em lei”
}

R. Fac. Dir. UFG, v. 38, n. 2, p. 149 - 176, jul. /dez. 2014

ISSN 0101-7187 
imorais e injustos. Na verdade, o conceito de desobediência civil é fluido e ainda está por se fixar. A definição acima apresentada constitui-se como simples moldura para melhor compreendê-la em uma perspectiva jurídico-crítica. É claro que tal moldura comporta importantes variações. Note-se, por exemplo, que depois de Gandhi - de sua teoria (GANDHI, 1951) e, com muito mais razão, de sua prática - não se pode sustentar que a desobediência civil caracteriza-se como postura individual (VARMA, 2002). Mahatma Gandhi foi talvez um dos primeiros líderes políticos a convencer grandes massas populacionais a desobedecer a ordem constituída, custasse o que custasse. É evidente que a partir de então não se pode desconsiderar o potencial coletivo da desobediência civil, que, tradicionalmente, sempre foi vista como contestação individual, a exemplo do contido na clássica obra de Thoreau.

Outro aspecto importante a se enfrentar na conceituação de desobediência civil diz respeito ao modo como tal postura se concretiza: por meio de atividades pacíficas - como a política da não-cooperação de Thoreau e de Gandhi, a exigência incondicional de paz feita por Tolstói e o repúdio ao mal e não às pessoas más, como pregava Luther King - ou, ao contrário, para ser eficaz a desobediência civil precisa assumir posturas violentas, lançando mão de recursos armados e da possibilidade de matar e morrer, como parecem insinuar Santo Tomás de Aquino, Thomas Hobbes, John Locke e Heinrich von Kleist? ${ }^{21}$ Caso se adote o viés agressivo da teoria da desobediência civil, seguramente a linha que a separa de grupos extremistas paramilitares será bastante tênue. Porém, não há que se dizer que posturas terroristas se enquadrem no conceito de desobediência civil. Ao contrário, o terrorismo não procura um diálogo com a ordem posta, tenta subvertê-la para impor uma nova ordem, buscando o poder por meios exclusivamente violentos.

Apesar dos vários problemas que envolvem a noção de desobediência civil - seu estatuto teórico, sua natureza jurídica, seus limites, etc. - é plenamente possível vislumbrar-lhe a riqueza, que somente agora começa a ser descoberta pela doutrina jurídica. Vivemos em uma

\footnotetext{
${ }^{21}$ Referimo-nos aqui, em uma perspectiva voltada para os ditames da corrente "Direito e Literatura", ao conto do escritor romântico alemão Heinrich von Kleist (1995) intitulado "Michael Kohlhaas", obra em que a dramaticidade da situação relativa ao personagem-título, oprimido pela escolha maldita entre o respeito à lei (autoridade) ou à honra (consciência individual), desemboca em algumas das páginas mais intensamente ferozes da literatura mundial, construindo assim uma concepção particularíssima de desobediência civil, que impressionou e arrancou comentários elogiosos de juristas tão diversos quanto Ost e Kelsen.
} 
época na qual a humanidade abriu mão de sua autonomia moral, deixando as decisões essenciais a respeito de sua existência para serem tomadas pela autoridade, seja ela jurídico-estatal ou financeira. Hoje a consciência individual capitula diante da autoridade. O homem individual não individualista ou egoísta, mas essencial, no sentido que ORTEGA Y GASSET (1983) dá ao termo - representa uma espécie em extinção.

A alienante sociedade de massas, a banalização das relações humanas, o domínio estatal estabelecido e mantido por tecnocracias financeiro-mundiais e a tendência ao aplainamento cultural do planeta por umas poucas potências belicistas são constatações que permeiam nosso quotidiano. Essa vaga pós-modernidade, na qual a humanidade apenas sobrevive, somente pôde se instalar devido ao abandono quase completo de algo que sempre caracterizou o homem: sua consciência individual. O reconhecimento do estatuto jusfundamental da desobediência civil, bem como a exposição das razões que ocasionaram sua desvalorização histórica pelo pensamento jusfilosófico aparecem como formas de salvaguardar - ou mesmo de resgatar - a dignidade da pessoa humana diante da massacrante e crua realidade do poder.

De fato, existem diversas formas de se posicionar diante da opressão de um Estado. Objeção de consciência, anarquismo e desobediência civil são formas de se resistir à opressão, à violência institucionalizada, aos mandamentos de um poder irracional, às leis que conformam o arcabouço de uma ordem. Não obstante, apesar da desobediência civil se assemelhar em algum ponto a tais fenômenos, carrega em si o pleno exercício da consciência individual, uma vez que não se encerra na permissão ou na vedação pelo poder estatal de sua realização. $O$ cidadão encontra-se na posição de indivíduo frente ao Estado e não como súdito que se dobra ao poder irresistível do Leviatã. Sem dúvida, a desobediência civil é um ato legítimo ante as não incomuns atrocidades do poder, fazendo parte do elenco dos chamados direitos fundamentais, sendo necessário considerá-la enquanto tal para se equacionar o problema das relações conflitivas entre autoridade e consciência individual no Estado Democrático de Direito.

Diferentemente do Brasil, outras ordens jurídicas preveem em seus textos constitucionais normas das quais se pode derivar diretamente nossa tese segundo a qual a 
desobediência civil é um direito fundamental. Nesse sentido, a Constituição da República Portuguesa de 1976 determina em seus artigos $7^{\circ}$ e $21^{\circ}$ :

[...] Artigo $7^{\circ}$ Portugal reconhece o direito dos povos à autodeterminação e independência e ao desenvolvimento, bem como o direito à insurreição contra todas as formas de opressão. [...]

Artigo $21 .^{\circ}$ Direito de resistência [...] Todos têm o direito de resistir a qualquer ordem que ofenda os seus direitos, liberdades e garantias e de repelir pela força qualquer agressão, quando não seja possível recorrer à autoridade pública. [...] (PORTUGAL, 1976, grifo nosso).

Da mesma forma, dispõe a Lei Fundamental da República Federal da Alemanha

em seu artigo 20:

1. A República Federal da Alemanha é um Estado federal democrático e social.

2. Todo poder do Estado emana do povo. Este poder é exercido pelo povo mediante eleições e votações e por intermédio de órgãos especiais dos poderes legislativo, executivo e judiciário.

3. O poder legislativo está submetido à ordem constitucional; os poderes executivo e judiciário, à lei e ao Direito.

4. Contra qualquer um que tente eliminar esta ordem, todos os alemães têm o direito de resistência quando não for possível outro recurso. [...] $]^{22}$ (ALEMANHA, 1949, grifo nosso)

A positivação do direito de se resistir à opressão, entendido como direito fundamental em alguns ordenamentos jurídicos modernos, representa uma limitação frente ao poder, tratandose de mecanismo interno do próprio Estado de Direito para impedir a violação dos direitos fundamentais tanto por parte daqueles que dominam a máquina estatal quanto por parte de terceiros.

\section{Conclusão}

22 “(1) La República Federal de Alemania es un Estado federal democrático y social. (2) Todo poder del Estado emana del pueblo. Este poder es ejercido por el pueblo mediante elecciones y votaciones y por intermedio de órganos especiales de los poderes legislativo, ejecutivo y judicial. (3) El poder legislativo está sometido al orden constitucional; los poderes ejecutivo y judicial, a la ley y al Derecho. (4) Contra cualquiera que intente eliminar este orden todos los alemanes tienen el derecho de resistencia cuando no fuere posible outro recurso." Original: “(1) Die Bundesrepublik Deutschland ist ein demokratischer und sozialer Bundesstaat. (2) Alle Staatsgewalt geht vom Volke aus. Sie wird vom Volke in Wahlen und Abstimmungen und durch besondere Organe der Gesetzgebung, der vollziehenden Gewalt und der Rechtsprechung ausgeübt. (3) Die Gesetzgebung ist an die verfassungsmäßige Ordnung, die vollziehende Gewalt und die Rechtsprechung sind an Gesetz und Recht gebunden. (4) Gegen jeden, der es unternimmt, diese Ordnung zu beseitigen, haben alle Deutschen das Recht zum Widerstand, wenn andere Abhilfe nicht möglich ist." (DEUTSCHLAND, 1949) 
Apesar das formulações jusnaturalistas (Sófocles, Santo Tomás de Aquino, Hobbes, Locke) que lhe deram substância, a noção de desobediência civil nunca encontrou seu locus teórico específico na tessitura filosófica do Direito. Tal se deve, em grande parte, à própria natureza da ideia, que guarda em si um forte matiz contestatório. Por outro lado, a verdadeira história do Direito e do Estado ainda está por se escrever, conforme sugere François Ost (2005), já que o pensamento jurídico tradicional, ao se comprometer com a orientação ideológica liberalcapitalista, acabou por se encerrar em si mesmo e, assim, desconsiderar - consciente ou inconscientemente - realidades muito ricas. Há toda uma teoria da desobediência civil a se desenvolver no campo estritamente jusfilosófico, apesar do avanço dos estudos relativos ao assunto na ciência e filosofia políticas, que, por óbvio, consideram o fenômeno por meio de perspectivas muito diversas daquela especificamente jurídica, que é exatamente a da decidibilidade.

Não obstante o tratamento lacunoso e superficial que se vem dispensando à noção de desobediência civil na seara jurídica - especialmente na Teoria do Estado e na Filosofia do Direito -, ainda assim pode-se enquadrá-la como um direito fundamental. A desobediência civil não configura uma exceção no Estado Democrático de Direito, uma espécie de último recurso para se utilizar em momentos de grave crise institucional. Ao contrário, a ideia de desobediência civil constitui, ao lado de outras noções caras ao pensamento liberal clássico (v.g., autonomia da vontade, proteção à propriedade, liberdade política), a própria base de tal tipo de Estado, sendo, portanto, um direito fundamental.

Se, como afirma o constitucionalismo contemporâneo, os direitos fundamentais se fundam na França revolucionária de 1789 e na Declaração de Independência Norte-Americana de 1776, parece-nos bastante claro que são necessários não apenas para originar o Estado de Direito, mas também - e principalmente - para sua manutenção. A desobediência civil, entre todos os outros direitos fundamentais, expressa a inalienável possibilidade de se "desfundar" o pacto político quando o mesmo tenha sido corrompido ou se mostrado excessivamente injusto e arbitrário. Se a soberania realmente pertence ao povo, e é graças a tal soberania que o Estado se 
mantém, não nos parece absurdo afirmar que aqueles que construíram o Estado podem, por diversos motivos, desconstruí-lo. Do contrário, a sociedade civil corre o risco de assumir a aventura sem volta da obediência cega à autoridade, que, interessada em maximizar o poder e o imperium, não hesita em sacrificar os direitos fundamentais, sejam eles quais forem, em nome das sempre obscuras raisons d'État.

Não se deve admitir que o Estado, a autoridade e o governo sejam vistos como monstros que, à semelhança das criaturas contidas na caixa de Pandora, escaparam definitivamente ao controle, nada se podendo opor à sua vontade de poder. Na verdade, são criações sociais que têm por missão a realização de finalidades igualmente sociais, sem o que não se justificam. A aceitação da desobediência civil como um dos direitos fundamentais representa uma espécie de garantia segundo a qual aqueles que concederam o poder podem retomá-lo a qualquer momento, desde que compareçam razões fortes o bastante para justificar a quebra do status quo. Nesse sentido, não falta à desobediência civil relevância jusfilosófica e evidência histórica, uma vez que originalmente compôs o rol de direitos fundamentais de primeira geração assumidos pelos revolucionários franceses de 1789.

\section{Referências Bibliográficas}

ALEMANHA, Lei Fundamental da República Federal da Alemanha, 1949. Disponível em: <http://www.brasil.diplo.de/contentblob/2677062/Daten/375140/ConstituicaoEspanhol_PDF.pdf $>$ Acesso em: 19 jul. 2011.

ARENDT, Hannah. Origens do totalitarismo: anti-semitismo, imperialismo, totalitarismo. Trad. Roberto Raposo. São Paulo: Companhia das Letras, 1989.

BITTAR, Eduardo. Teorias sobre a justiça: apontamentos para a história da filosofia, 2000.

BOBBIO, Norberto. GIANFRANCO, Pasquino. MATTEUCCI, Nicola (org.). Dicionário de política. Trad. Carmem C. Varriale et all; coordenação da tradução de João Ferreira. 2 vols. 5. ed. Brasília: UnB/São Paulo: Imprensa Oficial do Estado, 2000.

BOTTMANN, Denise. Lendo Walden, blog que reúne notas variadas de leitura e tradução de Walden, de Henry D. Thoreau. Disponível em: <http://lendowalden.blogspot.com>. Acesso em: 19 jul. 2011. 
BRASIL, Constituição da República Federativa do Brasil, 1988. Disponível em: <http://www.planalto.gov.br/ccivil_03/constituicao/constitui\%C3\%A7ao.htm>. Acesso em: 19 jul. 2011.

BRONDANI, Clóvis. Direito à Resistência na Filosofia de Thomas Hobbes. 2007. Dissertação (Mestrado em Filosofia) - Universidade Federal do Paraná. Setor de Ciências Humanas, Letras e Artes. Curitiba.

CARvajal A., Patrício. Derecho de Resistencia, Derecho a la Revolución, Desobediencia Civil: Una perspectiva histórica de interpretación. La formación del derecho público y de la ciencia política em la temprana Edad Moderna. Revista de Estudios Políticos (Nueva Época), n. 76. Abril-Junio, 1992.

COSTA, Nelson Nery. Teoria e realidade da desobediência civil. 2. ed., rev. e ampl. Rio de Janeiro: Forense, 2000.

DEUTSCHLAND, Grundgesetz für die Bundesrepublik Deutschland, 1949. Disponível em: <http://www.brasil.diplo.de/contentblob/2677068/Daten/750845/ConstituicaoAlemao_PDF.pdf>. Acesso em: 19 jul. 2011.

ESTADOS-UNIDOS, Declaração de Independência dos Estados-Unidos, 1776. Disponível em: < http://www.arqnet.pt/portal/teoria/declaracao.html>. Acesso em: 19 jul. 2011.

FERRAZ JÚNIOR, Tercio Sampaio. Introdução ao estudo do direito: técnica, decisão, dominação. 3. ed. São Paulo: Atlas, 2001.

FRANÇA, Déclaration des Droits de L'homme et du Citoyen de 1789. Disponível em: <http://www.assemblee-nationale.fr/histoire/dudh/1789.asp>. Acesso em: 19 jul. 2011.

GANDHI, Mohandas Karamchand. DUNCAN, Ronald Frederick Henry. Selected writings of Mahatma Gandhi. London: Faber and Faber, 1951.

GUADAluPE SILVEIRA, Luís Gustavo. A Teoria da Desobediência Civil de John Locke. Intuitio, v.1, n.2, pp. 218-231, novembro/2008.

HOBBES, Thomas. Leviatã: matéria, forma e poder de um estado eclesiástico e civil. Coleção "Os pensadores". Trad. João Paulo Monteiro e Maria Beatriz Nizza da Silva. São Paulo: Abril Cultural, 1977.

INGLATERRA, Bill of Rights, 1689. Disponível em: <http://www.dhnet.org.br/direitos/anthist/decbill.htm>. Acesso em: 19 jul. 2011.

KELSEN, Hans. Teoria Geral do Direito e do Estado. Trad. Luis Carlos Borges. São Paulo: Martins Fontes, 2000. 
KLEIST, Heinrich Von. A marquesa d'O e outras estórias. Rio de Janeiro: Imago, 1995.

LEGAZ Y LACAMBRA, Luis. El Estado de Derecho. Texto apresentado no Seminário sobre problemas atuais da Administração Pública, 16 de março de 1951.

LOCKE, John. Segundo tratado sobre o governo civil: ensaio sobre a origem, os limites e os fins verdadeiros do governo civil / John Locke ; introdução de J.W. Gough ; tradução de Magda Lopes e Marisa Lobo da Costa. Petrópolis: Vozes, 1994.

MENDES, Gilmar. Os direitos fundamentais e seus múltiplos significados na ordem constitucional. Revista Diálogo Jurídico, Salvador, CAJ - Centro de Atualização Jurídica, n. 10, janeiro, 2002. Disponível em: 〈http://www.direitopublico.com.br〉. Acesso em: 19 jul. 2011.

MENDES, Gilmar. Hermenêutica Constitucional e Direitos Fundamentais. Brasília: Brasília Jurídica, 2000.

MOORE JR., Barrington. Injustiça: as bases sociais da obediência e da revolta. São Paulo: Brasiliense, 1987.

ORGANIZAÇÃO DAS NAÇÕES UNIDAS. Declaração Universal dos Direitos Humanos da Organização das Nações Unidas, 1949. Disponível em:

<http://www.dhnet.org.br/direitos/deconu/textos/integra.htm〉. Acesso em: 19 jul. 2011.

ORTEGA Y GASSET, José. Obras completas. 12 vols. Madrid: Alianza/Revista de Occidente, 1983.

OST, François. Contar a lei: as fontes do imaginário jurídico. Trad. Paulo Neves. São Leopoldo: Unisinos, 2005.

PINA E SOUZA, Ruth Maria. Sade: O Poder do Gozo. 1993. Dissertação (Mestrado em Filosofia) - Universidade Estadual de Campinas. Instituto de Filosofia e Ciências Humanas, Campinas.

PORTUGAL, Constituição da República Portuguesa, 1976. Disponível em: <http://www.parlamento.pt/Legislacao/Paginas/ConstituicaoRepublicaPortuguesa.aspx>. Acesso em: 19 jul. 2011.

SADE, Donatien Alphonse F., marquês de. Diálogo entre um sacerdote y um moribundo. Compilado por Mario Pellegrini. Buenos Aires: Argonauta, 2005.

SADE, Marquês de. A filosofia na alcova. Trad., posfácio e notas Contador Borges. São Paulo: Iluminuras, 2008. 
SILVA, José Afonso da. Curso de Direito Constitucional Positivo. 18. ed. São Paulo: Malheiros 2000.

SÓFOCLES, Antígona. Versão para e-book, eBooksBrasil. Trad. J. B. de Mello e Souza. 2005. Disponível em <http://www.ebooksbrasil.org/adobeebook/antigone.pdf>. Acesso em: 19 jul. 2011.

SOLLERS, Philippe. Sade contra o Ser Supremo. Trad. Luciano Vieira Machado. São Paulo: Estação Liberdade, 2001.

THOREAU, Henry David. A desobediência civil. Porto Alegre: L\&PM, 2008.

THOREAU, Henry David. Desobedecendo: a desobediência civil \& outros escritos. 2. ed. Rio de Janeiro: Rocco, 1986.

VARMA, Vindra. Gandhi: poder, parceria e resistência. São Paulo: Palas Athena, 2002.

VALDES, Ernesto Garzon. El Terrorismo de Estado: El problema de su legitimación e ilegitimidade. Revista de Estudos Políticos (Nueva Epoca), nº. 65, julio-setembro, 1989. 